Mind and politics 



\section{Mind and politics}

An approach to the meaning of liberal

and socialist individualism

by Ellen Meiksins Wood

University of California Press

Berkeley, Los Angeles, London: 1972 
University of California Press

Berkeley and Los Angeles, California

University of California Press, Ltd.

London, England

Copyright $\odot 1972$ by The Regents of the University of California ISBN: 0-520-02029-4

Library of Congress Catalog Card Number: 74-153556

Designed by Theo Jung

Printed in the United States of America 
To my mother, Mischa, and Neal 
